\title{
The Preservation of Library Materials in Developing Countries
}

\author{
Ethleen Lastovica \\ South African Astronomical Observatory, P.O. Box 9, Observatory, \\ 7935, South Africa.e-mail: ethleen@saao.ac.za
}

\begin{abstract}
The acquisition of books and journals for a scientific library is costly. To ensure that this is a cost-effective process, consideration must be given to the arrangement, care and preservation of the collection. The books should be stored in a designated library area. Items acquired by purchase or donation must be catalogued, and a loan record kept. Besides regular library routines, attention must be given to the protection and preservation of the collection. Among the factors that contribute to the deterioration of library materials are temperature and humidity within the storage area, air pollution, dust, light and pests. Unchecked, they may cause serious damage to library materials at a very fast rate. If they are controlled, deterioration is greatly reduced.
\end{abstract}

\section{Introduction}

The acquisition of books and journals for scientific libraries is costly. To ensure that this is a cost-effective process, consideration must be given to the arrangement, care and preservation of the collection so that it does not deteriorate. There are many factors that pose a threat to library collections. For instance, the inherent chemical instability of acidic paper that begins to crumble as it ages; poor environmental conditions in storage areas - too light, too hot, too humid; too wet, too dry; careless handling and storage which causes physical and mechanical damage to books; biological enemies such as birds and animals, e.g. mice, rats, bats and even cats; insects; and micro-organisms which include moulds, fungi and bacteria; and vandalism, including theft.

The cost of professional library conservation is beyond the reach of many, if not most, library budgets. Even non-specialists charged with the responsibility of looking after an informal collection of books, can practice preventative care to establish and maintain better storage conditions in the library. The discussion that follows is not presented with large institutional libraries in mind, but is meant for the small library, which may, or may not, have a professional librarian in charge. Of course, the basics of good care and maintenance can be applied to book collections of any size, whether a small personal collection or a vast national library. 


\section{Organizing the Library}

It is pointless to apply preservation measures to a jumble of books and documents. Care starts with good management of the collection. If no formal library exists, an area that meets the environmental requirements for storage and is easily accessible to all staff should be used for the collection. It is necessary to know what is in the library, so formal cataloguing of the collection could be done either on cards or by using an electronic database. However, if the collection is small with few users, perhaps all that is needed is a handwritten ledger, or typed list. High-level cataloguing is not essential, but the title, author and date of publication should be recorded for each item. It is useful to assign a running accession number to each book or document. This serves two purposes - firstly it is a unique number that identifies a particular copy, and secondly, accession numbers indicate how many publications have been added to the collection.

In the cataloguing record, the location of the publication should be given. Simple shelf numbers could be used; e.g. section A, shelf 1 (A1), but more conventionally, books are grouped by subject. This is usually based on a standard classification system, such as Dewey.

In order to keep track of the stock, it is essential to maintain loan records. With a small number of users, this could be informal with the borrower writing the details in a loans book, or maybe signing an issue card that is left as a record of a book borrowed. Computerized loan records are being used increasingly in libraries, but care must be taken that the system does not become more sophisticated and time consuming than the size of the collection warrants.

\section{Preservation Assessment and Planning}

A clause in the Code of Ethics for Museums (American Association of Museums, 1994) could well apply to libraries and archives. It states that the institution must ensure that the "collections in its custody are protected, secure, unencumbered, cared for, and preserved".

Sherelyn Ogden defines preservation planning as a process by which the general and specific needs for the care of collections are determined, priorities are established, and resources for implementation identified (Northeast Document Conservation Center 1999, p.1). She stresses that while the plan must recognize all preservation needs, it should focus on those steps that can be accomplished with existing or obtainable resources.

Both Ogden and Greenfield (1988) outline the need for an assessment survey. In her book on The Care of Fine Books, Greenfield includes a two-page "Environmental Survey" form, which can be used for the identification of potential sources of harm to the library collection. It gives consideration to 9 areas of concern relating to the building structure; the climate within the building; fire prevention measures; flood control; security; biological problems from insects, animals and fungus; shelving; housekeeping and, the history of environmental problems. 


\section{Storage of Books}

\subsection{Desirable Conditions}

Once the collection has been brought into order, and the library area defined, it is essential to ensure that preventative care and maintenance is in place. Basements, attics and outbuildings are unsuitable locations for book storage. At worst, basements may become flooded, but more usually, the dark, damp, humid conditions adversely affect the paper and attract insects and rodents. Attics are too hot and dry, which causes paper to become brittle. Books stored in outbuildings are also likely to be attacked by insects and rodents, and with no protection from the weather, the books may well become brittle or mouldy.

The ideal environment includes controlled temperature and relative humidity, clean air with good circulation, controlled light sources, and freedom from biological infestation. Good housekeeping practices, security controls, and measures to protect collections from fire, water and other hazards complete the range of environmental concerns (IFLA 1998).

\subsection{Temperature, Relative Humidity and Light}

Ideally, the library should be weatherproof and free of biological infestations. The temperature and relative humidity $(\mathrm{RH})$ of the library area can affect the condition of the books. There is no ideal level for all types of library material but rather a range of values that vary according to the medium of the object being stored. Generally, high temperatures, with very dry air, are more harmful because the paper becomes desiccated. This is why the covers of a book left in the sun, or in front of a fire or heater, become buckled. If the room is constantly damp, and the relative humidity above $65 \%$, books can begin to fall apart, and when the $\mathrm{RH}$ rises over $75 \%$, moulds and fungus occur which will severely damage the library material.

There needs to be a careful balance between temperature and relative humidity in the library environment. Paper will retain its chemical stability and physical appearance for longer at a constant, low storage temperature (below $\left.10^{\circ} \mathrm{C} / 50^{\circ} \mathrm{F}\right)$ with a relative humidity of $30-40 \%$. For every $10^{\circ} \mathrm{C}\left(18^{\circ} \mathrm{F}\right)$ rise in temperature, the rate of chemical degradation reactions in traditional library and archival material such as paper and books, is doubled. Severe fluctuations or "cycling" of temperature and relative humidity will cause more damage than constantly high readings and so must be avoided (IFLA 1998).

Ultra-violet radiation from sunlight and fluorescent lighting causes irreversible fading and deterioration of paper, ink and bindings. Shelving should not be positioned in direct, or even indirect, sunlight. If necessary windows could be painted, or Venetian blinds or curtains hung to block out the offending light. Another option would be to have UV filtering film applied to windows.

\subsection{Pollution}

As might be judged by the preceding discussion, library material is susceptible to mould and fungal attack if poorly stored. Pollutants and high moisture content in the room are the likely catalysts for the growth of spores that can be a health hazard, as well as an enemy of library materials. For severe outbreaks of mould, expensive specialist treatment may be required. Fumigation is no 
longer recommended for mould because fumigants are toxic to people, the residue remains on the object, and it does not prevent the mould from returning. A far more cost-effective measure is to control the environment where the books are stored. This can be done by maintaining an acceptable temperature / relative humidity ratio; by circulating the air; by cleaning regularly with a vacuum cleaner fitted with a high efficiency particulate air (HEPA) filter; by not shelving books on an outside wall; by not having plants in the building; and by ensuring that the building is sound with no leaks or dampness (IFLA 1998).

\subsection{Insects and Pests}

Insects and pests can be as insidious as fungal spore. The insects that most commonly cause damage in libraries and archives throughout the world are cockroaches, silverfish or firebrats, book-lice, beetles and termites. They feed on the substances that books are made of, and lurk in the dark, damp, poorly ventilated places of the library. Insects cause irreparable physical damage to wood, paper, leather, fabric etc. Their presence is often indicated by tiny holes bored through the covers of books, or a lacework effect on pages caused by silverfish and firebrats that prefer to feast on modern wood-based paper, rather than the rag-based papers of past centuries. Wooden shelving can sometimes provide homes for wood-boring insects that are just as likely to attack books. Dean (1999) gives an account of a library in Vietnam whose wooden shelves were infested with wood-eating beetles; it was only after aluminum shelving was installed that the situation improved.

JICPA, the Joint ICA/IFLA Committee for Preservation in Africa has organized several workshops on the continent to raise awareness on preservation issues among African librarians and archivists. I spoke to some of the conservation specialists who participated in these workshops, and all recommended that non-specialists use simple, non-toxic measures to control pests. Johan Maree, Head of Book Conservation at the University of Cape Town, suggests placing laurel (bay) leaves Lauris nobilis) on the shelves behind the books, or else, placing Epsom salts or borax in small containers at the back of shelves. These are fairly effective means of controlling silverfish and the likes. The salts and borax should not be sprinkled on the shelves because the residue on books may be ingested accidentally by readers after handling the books. Commercial roach traps can also be used but they must be renewed every 3-6 months. The Roodepoort Museum, a cultural history museum in the northern part of South Africa uses Sunlight soap, which is pure, hard, laundry soap, as its only means of pest control. The soap is grated and then tied in a piece of fabric measuring approximately $15 \mathrm{~cm}^{2}$ (about $6 \mathrm{in}^{2}$ ). They have placed these little bags throughout their collections, including the library, and have found that they provide a very acceptable means of insect contol.

Greenfield (1998) says "termites are not a serious threat because they will presumably be dealt with long before they start on books." The IFLA manual (1998) is more accurate when it says that termites can devastate buildings and collections. Recently a university conservation department in the sub-tropical area of South Africa, moved into their newly built conservation laboratory. It was architect-designed to strict specifications, including cement floors. Some government publications left in the area in cardboard boxes were found to be 
have been shredded by termites over a weekend. The insects had entered the building through a small crack in the newly completed building.

Mice and rats can also cause devastation in libraries. Not only do they gnaw the books to obtain paper for their nests, but their droppings and urine cause metal shelves to corrode and the room to smell. Besides damaging books, rodents can also spread disease. Good housekeeping goes a long way to controlling rodents - clean floors, no food in the library area and wastebins emptied daily. Mouse and rat traps can be used to catch the intruders. Ultrasonic devices are also suggested as a deterrent, but in my experience, ultrasound has little effect. The least toxic treatment should always be preferred. If the infestation is severe, professional exterminators who understand the environmental requirements of libraries should be called in.

\section{Handling of Books}

Humans can cause just as much damage to books as environmental conditions and pests do. Greenfield (1988) lists 20 ways to treat books with care, most are self-evident. Whether an item is a printed book or an illuminated manuscript, all Greenfield's points essentially relate to respect for the item. Books should not be left in the sun, or accidentally wet. They should not be dropped, or spines cracked to make the book lie flat. Improper placemarkers (such as a fried egg! as I once saw in a public library exhibit) should not be used, nor should paper clips or pins be used for attaching supplementary notes to the page because they will rust over time.

Do not write in or near a book with an ink pen, and highlighter pens are out of place in a library. Pressure-sensitive tape, such as Sellotape, should not be used for book repair. Archival-quality document repair tape, obtained from specialist suppliers, is an acceptable means of repairing paper that is to be conserved. This tape is non-yellowing, neutral, reversible, transparent and pressure sensitive. Licking a finger to turn pages is unacceptable, this practice weakens the corners of pages, and in addition, if toxic substances have been used in the library for pest control, a person is likely to ingest some of the poison.

\section{Good Housekeeping}

Good and regular cleaning are essential to ensure the protection of the collection. Clean surroundings discourage fungi, insects and pests. The cleaning programme should include the examination of collections not only to provide early warning of biological or chemical damage, but also to observe conditions throughout the area.

Rooms used for storage should be sound in all respects and easy to clean and inspect. Like all good homes, air should circulate freely. This will ensure good climatic conditions in the areas where library material is stored. At the same time, an even climate should be maintained within the storage areas, with changes occurring as slowly as possible - as was said above, a cool room is better than a warm one because the growth of mould might occur. Floors should be vacuum-cleaned weekly. Library material on the shelves should only be cleaned by specially trained staff. Feather dusters are unsuitable for cleaning 
in this environment because they simply redistribute the dust; a duster to which particulates adhere should rather be used (Baynes-Cope 1990; IFLA 1998).

\section{Disaster Planning}

Although preparedness for disaster is a facet of library care and preservation, a detailed discussion of disaster planning is out of the scope of this presentation. Those responsible for preservation of collections need to give serious thought to preparedness for disasters that may be natural (floods, hurricanes etc.), or man-made, for example, acts of war, fires, water and explosions.

IFLA (1998) stresses that it is important to have a plan in place for coping with disasters if they occur. Disaster preparedness requires team effort from start to finish. It can be divided into five phases. A risk assessment needs to be undertaken to determine the potential dangers to buildings and their collections. Measures must be implemented to remove or reduce any danger - for example, light fittings repaired, plumbing, drainpipes and gutters kept in good condition and fire extinguishers serviced. Preparedness requires a written preparedness, response, and recovery plan. To minimize damage, response procedures to follow when disaster strikes must be well rehearsed. And finally there should be a recovery plan for restoring the disaster site and damaged material to a stable and usable condition.

\section{Collection Care in Southeast Asia}

Although recognized standards for library preservation lay down the foundation for good library management, it should be acknowledged that the approach to preservation should be carefully considered before being applied.

A paper given at the IFLA Conference in Bangkok in 1999 by John Dean, Director of the Department of Preservation and Conservation at Cornell University (www.library.cornell.edu/preservation) presents a new perspective on care and preservation with particular reference to Southeast Asia. Since 1987, Cornell University Department of Preservation has been actively involved in the preservation of collections in the upper regions of Southeast Asia, primarily Burma, Cambodia, Laos, Vietnam and Thailand. Cornell offers a six-month internship course for librarians and archivists from these areas to study achievable solutions to preservation problems, and the development of programs to acquire resources.

According to Dean (1999), the libraries and archives of Southeast Asia operate in a very different time frame, and have a different set of cultural and historical circumstances from those in the West. He draws attention to the fact that solutions to preservation problems are not entirely the same in the East as in the West, and the few attempts to inflict Western standards and practice, unaltered by locale, have been unsuccessful. He gives as an example the stock response to high levels of temperature and relative humidity by Westerners is to call for air conditioning systems to be installed. This can be a costly mistake in tropical regions, especially when books and manuscripts are removed from the controlled library environment, or the untrustworthy electricity supplies fail. In these circumstances, the drastic increase in temperature and relative humidity 
causes condensation on colder materials and interior walls and the consequent rapid development of mould.

\section{Care of Computer Disks}

Information stored on computer disk can be as priceless as the printed page. A brief mention needs to be made on the care of disks. An extensive search on the web located a site created by Skidmore College (2000) that is loaded with practical advice.

Never touch the disk surface; store disks in cool, dry places and always in a box of some kind; keep disks away from things that generate magnetic fields such as monitors, electric motors, telephones, and other electrical devices; don't bend disks - mail or transport them in rigid packaging; use a felt-tip pen to write on disk labels; make frequent backups of important information and store the backup away from your workplace; don't spill liquid on disks and don't use them as coasters for your drinks; and finally, never remove a disk while the drive light is on since this frequently results in deleting everything off the disk.

\section{Sources of Information on Preservation}

Two organizations, IFLA and NEDCC, are fully committed to encouraging worldwide cooperation for the preservation of library materials, and both provide outstanding resources on the web.

IFLA - the International Federation of Library Associations and Institutions, based in Paris has established a Core Programme for Preservation and Conservation (PAC) with regional centres in Asia (HQ - Tokyo), Latin America and the Caribbean (HQ - Caracas, Venezuela), United States/Canada (HQ - Washington, D.C.), Eastern Europe and the Commonwealth of Independent States (HQ - Moscow), and Western Europe, Africa and the Middle East (HQ - Paris, France). An excellent 74-page manual, IFLA Principles for the Care and Handling of Library Material is available free of charge on two websites, http://ifla.inist.fr/VI/4/pac.htm and http://www.clir.org.

The document is a general introduction to the care and handling of library material for individuals and institutions with little or no preservation knowledge. It does not provide detailed methods and practices, but gives basic information to assist libraries in establishing a responsible attitude to looking after their collections.

The NEDCC - Northeast Document Conservation Center, a non-profit American organization devoted to the preservation of library and archival materials, has had a strong commitment to the dissemination of information since its founding. Their 410-page manual on Preservation of Library and Archival Materials edited by Sherelyn Ogden (1999) can be freely downloaded from the web in English, Russian or Spanish (http://www.nedcc.org). It is also available in book form at a very reasonable cost.

Two additional inexpensive books that present practical advice on the care of books and documents in a concise, readable way are Caring for Books and Documents by A.D. Baynes-Cope (1990) and The Care of Fine Books by Jane 
Greenfield (1988). The cartoons illustrating the first book attract the reader to the informative text that was originally compiled by the British Library in response to the many queries they receive annually. The other book deals not only with the care, but also the repair of books, and provides very clear diagrams on how to do the various procedures.

Of course the importance of networking should not be overlooked. There is a strong network of astronomy librarians around the world who are always willing to provide assistance or advice to others if at all possible. The Directory of Astronomy Librarians and Libraries maintained by the library of the European Southern Observatory on the web at: http://www.eso.org/genfac/libraries/astro-addresses.html can help locate other librarians within one's geographical area or elsewhere.

A forum for electronic communication between astronomy librarians is provided by Astrolib, a project based at the National Radio Astronomy Observatory (library@nrao.edu). As a final thought, there is what Kathleen Robertson (1998) described as "A Clearinghouse for Astronomy Librarians: the PAM Web Site" (http://pantheon.yale.edu/ dstern/pamtop.html). This is the web site of the Physics-Astronomy-Mathematics Division of the Special Libraries Association. PAMnet, the electronic discussion list of the division, provides a forum for the discussion of library and information resource issues relevant to the fields of physics, astronomy and mathematics. It is open to subscribers who need not be PAM division members.

It may seem that I have strayed from my theme of preservation of library materials in developing countries, but the responsibility for preserving information for future generations is great, so therefore, the more we can share and discuss the challenges that face us, the more likely we are to succeed.

\section{References}

American Association of Museums 1994. Code of Ethics for Museums, rev. \& adapted 1993 (Washington, D.C.: AAM), 8.

Baynes-Cope, A.D. 1990. Caring for Books and Documents, 2nd ed. (New York: New Amsterdam Books).

Dean, J. 1999. Collection care and preservation of Southeast Asian materials. Int Preserv News, 20, 10 (http://ifla.inist.fr/VI/4/pac.htm).

Greenfield, J. 1988. The Care of Fine Books (New York: Lyons Press).

IFLA (International Federation of Library Associations and Institutions) 1998. IFLA Principles for the Care and Handling of Library Material, ed. E.P. Adcock, M.-T. Varlamoff, V. Kremp (Paris: IFLA). Electronic version: http://ifla.inist.fr/VI/4/pac.htm .

International Preservation News: a Newsletter of the IFLA Core Programme on Preservation and Conservation, no. 14, May 1997 + Electronic version: http://ifla.inist.fr/VI/4/pac.htm .

Northeast Document Conservation Center 1999. Preservation of Library $\mathcal{E}$ Archival Materials: a Manual, 3rd ed., ed. S. Ogden (Andover, MA.: NEDCC). Electronic version: http://www.nedcc.org . 
Robertson, A.K. 1998. A clearing house for astronomy librarians: the PAM web site. Library and Information Services in Astronomy III, ASP Conf. Ser. 153, eds U. Grothkopf et al., p.244. (San Francisco, ASP).

Skidmore College, Center for Information Technology Services, Saratoga Springs, NY 2000. Computing help@skidmore. http://www.skidmore.edu/help .

\section{Appendix: Useful Addresses}

IFLA Core Programme for Preservation and Conservation (PAC), International Focal Point, Bibliothque Nationale de France, T3 N4 97, Quai Franois Mauriac, 75706, Paris cedex 13, France. fax: +33-1-53-79-59-80; http://ifla.inist.fr/VI/4/pac.htm

Northeast Document Conservation Center, 100 Brickstone Square, Andover, MA 01810-1494, USA. fax: (978) 475-6021; http://www.nedcc.org 